\title{
Peroneal Pseudoaneurysm as a Complication of Emergency Thromboembolectomy and Treatment with Coil Embolisation
}

\section{Acil Tromboembolektominin Bir Komplikasyonu Olarak Peroneal Psödoanevrizma ve Koil Embolizasyon ile Tedavisi}

\author{
Kevser Tural, Tezcan Bozkurt*, Aykut Uyanık**, Ufuk Türkmen***, Zeynep Bilgi****, \\ ilknur Bahar***** \\ Kafkas University Faculty of Medicine, Department of Cardiovascular Surgery, Kars, Turkey \\ *Merkezefendi State Hospital, Clinic of Cardiovascular Surgery, Manisa, Turkey \\ **Pamukkale University Faculty of Medicine, Department of Emergency Medicine, Denizli, Turkey \\ ***Salihli State Hospital, Clinic of Cardiovascular Surgery, Manisa, Turkey \\ $* * * *$ Harakani State Hospital, Clinic of Chest Surgery, Kars, Turkey \\ *****Türkiye Yüksek Ihtisas Educations and Research Hospital, Clinic of Cardiovascular Surgery, Ankara, Turkey
}

\section{Abstract}

Peroneal pseudoaneurysm is a rarely seen as a complication due to a variety of treatment strategies. Continuous blood flow and decreased vascular wall support associated with pseudoaneurysm can cause rapid enlargement, compression of venous and nerve structures, rupture and mortality.

An 84-year-old female patient presented to the emergency department with sudden onset pain and paleness in the right lower extremity. Doppler ultrasound revealed thrombus in the right common femoral artery. The patient underwent emergency embolectomy. Doppler ultrasound due to continuing symptoms on postoperative day one showed $23 \times 30 \mathrm{~mm}$ pseudoaneurysm of the distal third of the right peroneal artery. Left femoral artery was catheterised and the peroneal artery aneurysm was coil embolised successfully.

Timely diagnosis of complications and rapid treatment are essential in patients with recent vascular interventions. Palpable pulses and intact neurological examination do not rule out most of the complications which would require surgery for correction.

Keywords: Embolectomy, pseudoaneurysm, coil embolisation

\section{Öz}

Peroneal psödoanevrizma çeşitli tedavi stratejileri nedeniyle nadiren bir komplikasyon olarak görülür. Psödoanevrizmaya bağlı devamlı kan dolaşımı ve vasküler duvar desteğinin azalması, hızlı büyümeye, venöz ve sinir yapılarının sıkışmasına, rüptür ve mortaliteye neden olabilir.

Seksen dört yaşında kadın hasta sağ alt ekstremitede ani başlayan ağrı ve solukluk ile acil servise başvurdu. Doppler ultrasonografide sağ femoral arterde trombüs saptandı. Hastaya acil embolektomi uygulandı. Postoperatif 1. günde devam eden semptomlardan dolayı Doppler ultrasonografide sağ peroneal arterin distal üçte birinde $23 \times 30$ mm psödoanevrizma saptandı. Sol femoral arter kateterize edilerek peroneal arter psödoanevrizması koil ile embolize edildi.

Komplikasyonların zamanında tanı alması ve hızlı tedavisi, yakın zamanda vasküler müdahaleleri olan hastalar için önemlidir. Palpabl nabızlar ve bozulmamış nörolojik muayene, ameliyat ile düzeltilmesi gereken komplikasyonların çoğunu ekarte etmez.

Anahtar Sözcükler: Embolektomi, psödoanevrizma, koil embolizasyon
Address for Correspondence/Yazışma Adresi: Kevser Tural Kafkas University Faculty of Medicine, Department of Cardiovascular Surgery, Kars, Turkey E-mail: ktrl2011@hotmail.com ORCID ID: orcid.org/0000-0003-4490-037X

Received/Geliş Tarihi: 07 May 2017 Accepted/Kabul Tarihi: 19 June 2017
${ }^{\circ}$ Copyright 2017 by The Medical Bulletin of University of Health Sciences Haseki Training and Research Hospital
The Medical Bulletin of Haseki published by Galenos Yayınevi.

๑Telif Hakkı 2017 Sağlık Bilimleri Üniversitesi Haseki Eğitim ve Araştırma Hastanesi Haseki Tıp Bülteni, Galenos Yayınevi tarafindan basılmışıı. 


\section{Introduction}

Peroneal pseudoaneurysm is a rarely seen complication associated with a variety of treatment strategies. In this article, we present a case of iatrogenic peroneal pseudoaneurysm secondary to femoral embolectomy which was successfully treated with coil embolism.

\section{Case}

An 84-year-old female was admitted to the emergency department with a three-hour history of pain and paleness in the right lower extremity. Physical examination revealed absent distal pulses in the affected extremity. Motor and sensory examination was normal. Electrocardiography revealed a newly diagnosed atrial fibrillation. Doppler ultrasound (USG) and digital subsraction angiography were consistent with acute embolism of the right common femoral artery. Echocardiography did not show a cardiac thrombus.

An uncomplicated right femoral embolectomy was performed. Continued symptoms prompted another control Doppler USG despite palpable pulses and nonischemic clinical picture in the subsequent clinic follow-up. A pseudoaneurysm in the distal right peroneal artery was seen with patent anterior tibial artery, posterior tibial artery and popliteal artery. The left femoral artery was accessed to catheterise the right femoral artery; angiographic examination revealed multilobulated peroneal artery pseudoaneurysm (Figure 1). Coil embolisation of the distal peronal artery successfully stopped blood flow

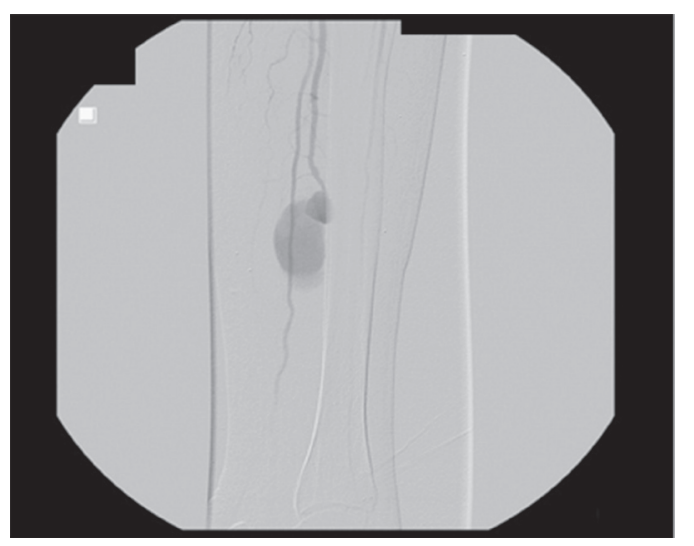

Figure 1. Angiographic view of peroneal artery pseudoaneurysm

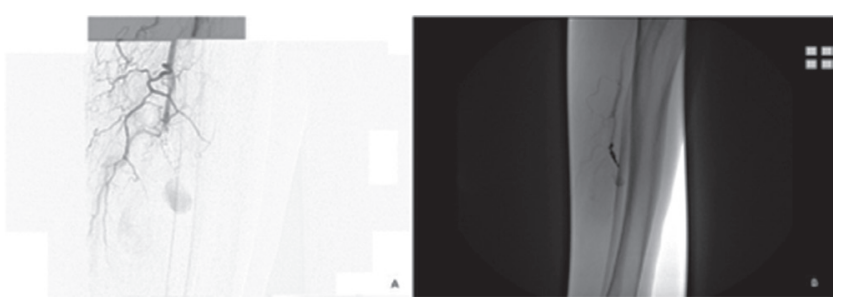

Figure 2. Coil embolisation (A) and succesfull obliteration (B) of the peroneal artery pseudoaneurysm in the pseudoaneurysm, verified by a control angiography (Figure 2). The patient was discharged on postoperative day three without any further complications.

\section{Discussion}

Most of the peripheral artery pseudoaneurysms occur secondary to trauma. Diagnostic and therapeutic interventions are the commonest reasons for trauma (1). Infections and surgical procedures can also rarely lead to pseudoaneurysm formation (2). Continuous blood flow and decreased vascular wall support of a pseudoaneurysm can cause rapid enlargement, compression of venous and nerve structures, rupture and mortality (3).

Doppler USG is commonly used in the diagnosis of peripheral artery pseudoaneurysms due to ease of use. Toand-fro flow pattern and ying-yang sign are characteristic and lead to rapid diagnosis (4). Angiography is essential and the gold standard in pseudoaneurysms for evaluation of exact anatomic structure, distal flow and also endovascular treatment in the same session $(5,6)$.

The anatomic structure of the involved artery, the perfusion and collateral circulation must be taken into account in the treatment. Simple ligation may be enough for pseudoaneurysms originating from arteries with ample collaterals like ulnar, tibial and peroneal arteries. Other approaches for preservation of arterial continuity are primary surgical repair, resection and endto-end anastomosis, saphenous vein patch, stenting the pseudoaneurysm neck, coil embolisation (4) and compression with thrombin injection (7).

Pseudoaneurysms smaller than $20 \mathrm{~mm}$ can spontaneously regress and may be amenable to observation (8). Minimally invasive approaches should be the first choices if possible, necessary surgery should not be delayed due to increased morbidity $(5,7)$.

Peroneal pseudoaneurysms secondary to trauma and surgical interventions are rarely seen. Here, we present a case of iatrogenic peroneal artery pseudoaneurysm secondary to embolectomy with a Fogarty catheter and successful treatment with coil embolisation instead of surgical repair.

\section{Ethics}

Informed Consent: Verbal informed consent was obtained from patients who participated in this study.

Peer-review: Externally peer-reviewed.

\section{Authorship Contributions}

Surgical and Medical Practices: I.B., K.T., U.T., T.B. Concept: K.T., T.B., U.T. Design: K.T., T.B., U.T. Data Collection or Processing: K.T., T.B., U.T., Z.B., I.B. Analysis 
or Interpretation: K.T., A.U, Z.B., I.B. Literature Search: K.T., T.B., U.T. Writing: K.T., T.B., U.T., Z.B., I.B.

Conflict of Interest: No conflict of interest was declared by the authors.

Financial Disclosure: The authors declared that this study received no financial support.

\section{Referanslar}

1. Wery D, Delcour C, Jacquemin C, Richoz B, Struyven J. latrogenic femoral pseudo-aneurysm. Analysis of the causes, diagnosis and treatment. Study of 12,248 arterial catheterizations. J Radiol 1989;70:609-11.

2. Ting AC, Cheng SW. Femoral pseudoaneurysms in drug addicts. World J Surg 1997;21:783-6.

3. Canbaz S. Periferik arter anevrizmaları. İçinde: Duran E, editör. Kalp ve damar cerrahisi. İstanbul: Çapa Tıp Kitapevi; 2004. s. 783-98.
4. Kırali K, Güler M, Mansuroğlu D, ve ark. Ekstremite arterlerinin psödoanevrizmaları ve tedavisi. Türk Göğüs Kalp Damar Cer Derg 2000;8:802-4.

5. Thalhammer C, Kirchherr AS, Uhlich F, Waigand J, Gross CM. Postcatheterization pseudoaneurysms and arteriovenous fistulas: Repair with percutaneous implantation of endovascular covered stents. Radiology 2000;214:127-31.

6. Chong KC, Yap EC, Lam KS, Low BY. Profunda femoris artery pseudoaneurysm presenting with triad of thigh swelling, bleeding and anaemia. Ann Acad Med Singapore 2004;33:267-9.

7. Kang SS, Labropoulos N, Mansour MA, Baker WH. Percutaneous ultrasound guided thrombin injection: a new method for treating postcatheterization femoral pseudoaneurysms . J Vasc Surg 1998;27:1032-8.

8. Clark ET, Gewertz BL. Pseudoaneurysms. In: Rutherford RB, editor. Vascular Surgery. Philadelphia: W.B. Saunders Company; 1995. p. 1153-61. 